WOJCIECH KOSIOR ${ }^{1}$

\title{
The stages of human life distinguished in non-legal Roman sources
}

\begin{abstract}
The age of a human being is a common research topic in many branches. This topic is also addressed by the legal theory. Age categories also functioned in Roman law, determining the legal position of a person. In this article, the non-judicial sources which concerned the division of human life are analyzed. Consequently, it has been possible to determine that in ancient Rome, there were several theories concerning this matter. The division of life into three, four, five, six or seven stages was very popular. Each theory has different justifications and various arguments. Among those, we can distinguish medical, psychological, numerical and also military-administrative arguments.
\end{abstract}

Keywords: Roman law, ancient Rome, age, infancy, youth, old age, non-legal sources

Wojciech Kosior - Assistant Researcher, Chair of Civil Law and Roman Law, Faculty of Law and Administration, University of Rzeszów, Public Prosecutor's Trainee, National School of Judiciary and Public Prosecution; e-mail: wojciech.kosior@gmail.com. 


\section{WOJCIECH KOSIOR}

\section{Etapy życia człowieka w pozaprawnych źródłach rzymskich}

\section{Streszczenie}

Wiek człowieka jest popularnym przedmiotem badawczym wielu dziedzin nauki i ich pochodnych. Przedmiot ten wykorzystywany jest również przez naukę prawa. W prawie rzymskim również funkcjonowały kategorie wieku, od przekroczenia których zależała pozycja prawna danej osoby. W artykule poddano badaniu rzymskie źródła nieprawnicze traktujące o podziale życia ludzkiego na etapy. W efekcie przeprowadzonych badań udało się ustalić, iż w starożytnym Rzymie funkcjonowało kilka teorii na ten temat. Popularnymi klasyfikacjami był podział życia człowieka na trzy, cztery, pięć, sześć oraz siedem etapów. U podstaw każdej teorii leży inne uzasadnienie i inne argumenty. Wśród tych można wskazać argumenty medyczne, psychologiczne, numerologiczne a nawet poniekąd wojskowo-administracyjne.

Słowa kluczowe: Prawo rzymskie, starożytny Rzym, wiek, dzieciństwo, młodość, starość, źródła nieprawnicze 
$\mathrm{T}$ he age of a human being is a common research topic in many branches. This topic is also addressed by the legal theory. In commonly binding legal acts, both Polish and foreign ones, we can find a significant number of examples which confirm the thesis presented above. Legal provisions such as those referring to the age, the capacity to act in law, criminal liability or public rights should be pointed out. There are no doubts that setting such age limits was socially justified. Such boundaries were not set randomly. The legal theory which researches the subject of human age starts at this point. It should be underlined that the research of age categories should be, from the legal point of view, linked to the analysis of non-legal sources which present the communal and social background, and also demographic aspects. As a consequence thereof, it can be pointed out what stood behind the adoption of particular resolutions and legal provisions determining the boundaries of age.

Age categories also functioned in Roman law, in accordance with which the legal position of a person was determined. ${ }^{2}$ The ages of 7, 12, 14 and 25 together with the adjusted terms such as infantes, impuberes and puberes were characteristic of the Roman private law.

The main aim of this article is to present and describe the stages of human life distinguished in ancient Rome on the basis of non-juridical sources.

The oldest and smallest in number division of human life into stages in ancient Rome was the three-stage classification suggested in royal times by king Servius Tullius, ruling from $578 \mathrm{BC}$ to $534 \mathrm{BC}$. Information concerning this division can be found in the work of a Roman writer and grammarian Aulus Gellius, who in

2 About the age categories in Roman law, cf.: M. Kuryłowicz, A. Wiliński, Rzymskie prawo prywatne. Zarys wykładu, Warszawa 2008, pp. 101 et seq.; A. Dębiński, Rzymskie prawo prywatne. Kompendium, Warszawa 2011, pp. 147 et seq.; K. Kolańczyk, Prawo rzymskie, Warszawa 1986, pp. 208 et seq.; W. Wołodkiewicz, M. Zabłocka, Prawo rzymskie. Instytucje, Warszawa 2009, pp. 114 et seq.; W. Osuchowski, Rzymskie prawo prywatne. Zarys wyktadu, Warszawa 1981, pp. 186 et seq.; W. Dajczak, T. Giaro, F. Longchamps de Bérier, Prawo rzymskie. U podstaw prawa prywatnego, Warszawa 2009, pp. 191 et seq.; R. Taubenschlag, Rzymskie prawo prywatne, Warszawa 1969, pp. 109 et seq.; W. Litewski, Rzymskie prawo prywatne, Warszawa 1990, pp. 143 et seq.; M. Żołnierczuk, Zarys prawa rzymskiego, Lublin 1998, p. 96 et seq.; M. Kaser, Das Römische Privatrecht, München 1955, pp. 238-240; И.Б. Новицкий, Римское право: учебник, Москва, 2009, pp. 60-61; R. Świrgoń-Skok, Kategorie wieku w prawie rzymskim, "Zeszyty Naukowe Uniwersytetu Rzeszowskiego, Seria Prawnicza" 2013, 77, pp. 144 et seq.; W. Kosior, Kategorie wieku w prawie rzymskim okresu królewskiego, "Zeszyty Naukowe Uniwersytetu Rzeszowskiego, Seria Prawnicza" 2015, 89, pp. 9 et seq. 
his Noctes Atticae $e^{3}$, calls the following passage of the Roman lawyer Quintus Aelius Tubero:

Aul. Gell, NA, 10, 28: Tubero in historiarum primo scripsit Servium Tullium regem, populi Romani cum illas quinque classes ${ }^{4}$ seniorum et iuniorum census faciendi gratia institueret, pueros esse existimasse, qui minores essent annis septem decem, atque inde ab anno septimo decimo, quo idoneos iam esse reipublicae arbitraretur, milites scripsisse, eosque ad annum quadragesimum sextum "iuniores" supraque eum annum "seniores" appellasse. Eam rem propterea notavi, ut discrimina, quae fuerint iudicio moribusque maiorum pueritiae, iuventae, senectae, ex ista censione Servi Tulli, prudentissimi regis, noscerentur.

As follows from the above mentioned passage, king Servius Tullius made a division according to the ability to perform military duty. Consequently, boys under the age of 17 were called pueri, and were released from military duty, people between 17 and 46, called iuniores were appointed to perform the duty and after the age of 46 they were called seniores and did not perform duty in the military. ${ }^{5}$ Quintus Aelius Tubero in this passage also states that, the division made by king Servius Tullius into childhood, youth and old age (pueritiae, iuventae, senectae) was created by a judicial decision and had been used in previous times.

Table 1. Three stages of human life according to Servius Tullius

\begin{tabular}{cc}
\hline Stage & Age \\
\hline Childhood (pueritia) & below 17 years \\
Youth (iuventa) & $17-46$ years \\
Old age (senecta) & above 46 years \\
\hline
\end{tabular}

Upon inquiry into the next, four-stage division of life in ancient Rome, two different grounds can be found for the acceptance of such a classification. On the one hand, we deal with a division suggested by a Roman doctor with Greek roots,

3 Cf: J.C. Rolfe, Aulus Gellius: Attic Nights, Vol. II, Books 6-13, Harvard 1927, p. 576.

4 The term quinque classes refers to the division of the Roman society into five financial classes by king Servius Tullius.

5 C.G. Harcum, The Ages of Man: A Study Suggested by Horace, Ars Poetica, Lines 153-178, "The Classical Weekly" 1914, 7(15), p. 115. 


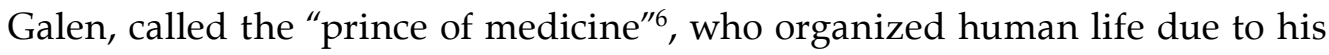
medical knowledge. On the other hand, Roman writers, such as Cicero and Horace, based their theories on spiritual and psychological consideration, determining the needs of humans.

Galen based his theory on the Greek scholar Hippocrates, who created a division of human life in his work entitled De Natura Humana, which was based on the humoral theory which is a quasi-scientific view about the fact of a human being consisting of four basic liquids: blood, phlegm, bile and black bile. ${ }^{7}$ According to the assumptions of this theory, the elements, called humors, reflected four seasons of the year, four kinds of human character ${ }^{8}$, four elements and four stages of human life. ${ }^{9}$ The concept relies on a statement that human life is a reflection of the nature and the human body is its part. ${ }^{10}$ Galen, in his works De Placitis Hippocratis et Platonis and Galeni in Librum Hippocratis de Natura Humana, establishesa connection among humors, seasons and stages of life. The blood is linked with spring and childhood

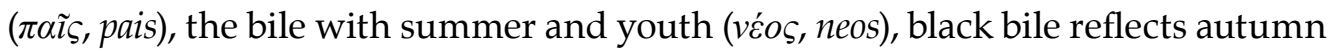
and maturity ( $\pi \alpha \rho \alpha \kappa \mu \alpha \dot{\zeta}(\omega$, parakmazo), and phlegm is linked to winter and old age $\left(\gamma \tilde{\eta} \rho \alpha \varsigma\right.$, geras $\left.^{11}\right)$. However, linking the life stages with a particular age limit, gives rise to a question that should be discussed. The direct connection between humor, season and particular ages of life is expressed only once in the work de Natura Humana. That is, in Galeni in Librum Hippocratis de Natura Humana, Gaius blames black bile for high fever which occurs during a sickness every four days. ${ }^{12} \mathrm{He}$ adds that such fever and the sickness linked to it affects adults between the ages of 25 and 45 ,

6 Cf.: S.P. Mattern, The Prince of Medicine. Galen in the Roman Empire, New York 2013, p. 341.

$7 \quad$ Also, a point of view can be found according to which in the humor theory the following ones dominated: blood, phlegm, bile and water. See: J. Jouanna, Greek Medicine from Hippocrates to Galen. Selected papers, Leiden-Boston 2012, p. 336.

8 In this case, it refers to a sanguine, spitfire, phlegmatic and melancholic.

9 About the division of life into four stages by Galen and Hippocrates cf.: Ch. Laes, J. Strubbe, Youth in the Roman Empire. The Young and the Restless Years?, Cambridge 2014, pp. 24-25; Ch. Laes, Children in the Roman Empire. Outsiders within, Cambridge 2011, pp. 86-87; G.E.R. Lloyd, The Hot and the Cold, the Dry and the Wet in Greek Philosophy, "The Journal of Hellenic Studies" 1964, 84, pp. 92-106; J.R. Coxe, The writings of Hippocrates and Galen, Philadelphia 1846, p. 692; P. de Lacy, Galen, On the doctrines of Hippocrates and Plato. Translation and Commentary, Berlin 2005, p. 256; J. Longrigg, Greek Rational Medicine: Philosophy and Medicine from Alcmaeon to the Alexandirans, London 1993, p. 308.

10 J. Gollnick, Religion and Spirituality in the Life Cycle, New York 2005, p. 35.

11 Apart from the term $\gamma \tilde{\eta} \rho \alpha \varsigma$ (geras), the term $\gamma \varepsilon \dot{\varepsilon} \rho \omega$ (geron), meaning „old man”, was used in ancient Greece to refer to an old man, which meant a person between the age of 60 to 80, cf.: R.L. Overstreet, The Greek Concept of the "Seven Stages of Life" and Its New Testament Significance, "Bulletin for Biblical Research" 2009, 19(4), pp. 349, 546.

12 High fever occurring every four days is a characteristic feature of the so called four-day jungle fever or quartana which is a kind of jungle fever called Malaria quartana. 
and those ages are further linked with autumn. Such a presentation would prove that Galen believed people of such ages to be mature $(\pi \alpha \rho \alpha \kappa \mu \dot{\alpha} \zeta \omega) .{ }^{13}$ This would lead to the conclusion that for Galen, old age would commence after the age of 45 . However, there is also a view in literature that Galen determines old age as starting after 60 and this view is believed as dominant. ${ }^{14}$ Nevertheless, as pointed by C. Skenazi, some doubts in reference to this view appeared in the period of Renaissance..$^{15}$ Such doubts are probably the effect of the fact that Galen, besides the common scientific view of dividing human life into four stages, also distinguished an almost forgotten sub-division, which is the one of three stages of old age. In his work De Sanitate tuenda, he distinguished the following types of old age: green, regular and fading old age on the basis of hydration and warmth of the human body. ${ }^{16}$ In such a presentation of the case, it can be assumed that, according to Galen, a human being after the age of 45 was entering the stage of green old age, where a human being still remained very active, and after the age of 60 , regular old age started, which forced a change of life.

Table 2. Four stages of life according to Galen (two options)

\begin{tabular}{ccc}
\hline Stage & \multicolumn{2}{c}{ Age } \\
\hline Childhood $(\pi \alpha \tilde{\iota} \varsigma$, pais) & below 15 years & below 25 years \\
Youth $(v \varepsilon \dot{o} \varsigma$, neos) & $15-25$ years & $25-40$ years \\
Maturity $(\pi \alpha \rho \alpha \kappa \mu \dot{\alpha} \zeta \omega$, parakmazo) & $25-45$ years & $40-60$ years \\
Old age $(\gamma \tilde{\eta} \rho \alpha \varsigma$, geras $)$ & over 45 years & over 60 years \\
\hline
\end{tabular}

A four-stage division of human life is also suggested by Horace and Cicero. In their cases, however - in distinction to the medical theories of Galen - the division of life into four stages is linked more to the mental development of human life, rather than physical one. Cicero determined the stages of human life on the basis of the current preferences of man.

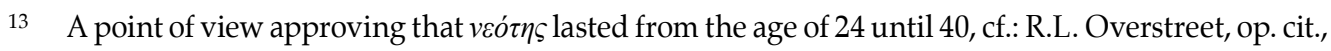
pp. 541-545.

14 Cf.: C. Skenazi, Aging Gracefully in the Renaissance: Stories of Later Life from Petrarch to Montaigne, Leiden-Boston 2013, p. 17; Ch. Laes, J. Strubbe, op. cit., p. 25; Ch. Laes, op. cit., p. 87.

15 C. Skenazi, op. cit., p. 17 - "Galen's fourfold division of life, in which old age (geron) begins at around sixty, prevailed as part of the fourfold humoral scheme, although some fluctuations persisted even beyond the Renaissance."

16 Ibidem, p. 17-18. 
Cic. Sen. 76, (...) omnino, ut mihi quidem videtur studiorum omnium satietas vitae facit satietatem. sunt pueritiae studia certa: num igitur ea desiderant adulescentes? sunt ineuntis adulescentiae: num ea constans iam requirit aetas, quae media dicitur? sunt etiam eius aetatis: ne ea quidem quaeruntur in senectute. sunt extrema quaedam studia senectutis: ergo, ut superiorum aetatum studia occidunt, sic occidunt etiam senectutis; quod cum evenit, satietas vitae tempus maturum mortis affert.

As follows from the above mentioned passage - which is part of a work fully devoted to the last stage of life, i.e. old age $\mathrm{e}^{17}$ - a human being has various preferences and inclinations throughout his life, which fade away and occur one after another. Cicero points out that an adolescent does not want the same things as he did when he was still a child. After youth there is stable age, called medium age. Later, there is old age, which also has its own preferences. After the disappearance of these preferences, human life loses its charm and then it is time for death.

Cicero wrote about the differences dividing youth and old age:

Cic. Sen. 72, senectutis autem nullus est certus terminus, recteque in ea vivitur, quoad munus offici exsequi et tueri possit mortemque contemnere, ex quo fit ut animosior etiam senectus sit quam adulescentia et fortior.

An image of an old man appears in this extract, i.e. that of a human being who possesses more courage and serenity than a young person. According to Cicero, this is a consequence of the fact that each stage of human life, except old age, has its own determined end (certus terminus). Old age lasts as long as a human being can properly fulfill all duties without the fear of death. This means that an old person finds his courage and serenity in this particular matter. For example, a young person is conscious of time passing by and of the fact that he will enter into another stage of life, which - according to Cicero - takes away his courage and disrupts his serenity.

Cicero was about 62 years old while writing the work in question. ${ }^{18}$ In it, he described himself as a person close to death. ${ }^{19}$ In reference to the above mentioned information, which is the age of Cicero, being a person close to death, and the

17 Cf.: Z. Cierniakowa, Cyceron - Plutarch. Pochwała starości, Warszawa 1996, p. 158; W.A. Falconer, Cicero: De Senectute De Amicitia De Divinatione. With An English Translation, Harvard 1923, p. 576.

18 Ch. Laes, J. Strubbe, op. cit., p. 25.

19 Cic. Sen. 77: non enim video, cur, quid ipse sentiam de morte, non audeam vobis dicere, quod eo cernere mihi melius videor, quo ab ea propius absum. 
four-stage division of human life, it can be stated that each of the stages had a certain age span, thus:

Table 3. Four stages of human life according to Cicero

\begin{tabular}{cc}
\hline Stage & Age \\
\hline Childhood (pueritia) & $0-16$ years \\
Youth (adulescentia) & $16-33$ years \\
Stable age/ medium (constans/mediaaetas) & $33-50$ years \\
Old age (senectus) & over 50 years \\
\hline
\end{tabular}

Horace performed a division of human life into four stages in his work Ars Poetica $^{20}$ in the following way:

Hor. Ars 161 (...) tu, quid ego et populus mecum desideret, audi, si plausoris eges aulaea manentis et usque sessuri, donec cantor 'vos plaudite' dicat. aetatis cuiusque notandi sunt tibi mores, mobilibusque decor naturis dandus et annis. reddere qui voces iam scit puer et pede certo signat humum, gestit paribus conludere et iram colligit ac ponit temere et mutatur in horas. inberbis iuvenis, tandem custode remoto, gaudet equis canibusque et aprici gramine campi, cereus in vitium flecti, monitoribus asper, utilium tardus provisor, prodigus aeris, sublimis cupidusque et amata relinquere pernix. conversis studiis aetas animusque virilis quaerit opes et amicitias, inservit honori, conmisisse cavet quod mox mutare laboret. multa senem circumveniunt incommoda, vel quod quaerit et inventis miser abstinet ac timet uti, vel quod res omnis timide gelideque ministrat, dilator, spe longus, iners avidusque futuri, difficilis, querulus, laudator temporis acti se puero, castigator censorque minorum. multa ferunt anni venientes commoda secum, multa recedentes adimunt: ne forte seniles mandentur iuveni partes pueroque viriles: semper in adiunctis aevoque morabitur aptis. aut agitur res in scaenis aut acta refertur. segnius inritant animos demissa per aurem quam quae sunt oculis subiecta fidelibus et quae ipse sibi tradit spectator: non tamen intus digna geri promes in scaenam multaque tolles ex oculis, quae mox narret facundia praesens: ne pueros coram populo Medea trucidet aut humana palam coquat exta nefarius atreus aut in avem Procne vertatur, Cadmus in anguem, quodcumque ostendis mihi sic, incredulus odi.

20 Cf.: C. Smart, Horace. The Works of Horace, Philadelphia 1836, p. 425; C. Smart. T.A. Buckley, Horace. The Works of Horace, New York 1863, p. 365. 
This extract shows that Horace distinguished four stages in the life of a man - i.e. childhood ( puer $^{21}$ ), adolescence (inberbis iuvenis), the years before adulthood (anni venientes) and the years after adulthood leading to old age (anni recedentes).

The feature of childhood is learning to say words, making first steps and playing. It is also natural to experience sudden mood changes even within one hour. After the age of childhood there is the time of adolescence. Inberbis iuvenis determines a young man without a beard. ${ }^{22}$ According to Horace, this is the time when a person stops being under the power of a guardian. ${ }^{23}$ An adolescent spends a lot of time playing with dogs and horses, remaining mainly on sunny glades. Other features are hostility towards all advisors and extravagance. Next, there are two stages in life which occur one after another, i.e. anni venientes and anni recedentes, being preceding and departing ages. In the first case, it is about the time of the greatest activity and maturity of a person. This period is characterized by the connection of a relevant age, masculinity, honor and wealth. A human being of that age is careful and takes pre-analyzed decisions. The time which leads to old age is called anni recedentes. This age, according to Horace, brings many advantages but also takes away many others.

Horace, while preparing the work in question, was about 51 years old and also described himself - similarly to Cicero - as an old man slowly approaching death. ${ }^{24}$

While discussing the four-stage division of human life, it is impossible not to mention Florus, a Roman historian, who presented the historical stages of the evolution of Rome in a similar and interesting way. This text does not refer to human life directly but points towards the popularity of a four-stage classification in Roman sources.

Flor. Epit. I, Si quis ergo populum Romanum quasi unum hominem consideret totamque eius aetatem percenseat, ut coeperit utque adoleverit, ut quasi ad quandam iuventae frugem pervenerit, ut postea velut consenuerit, quattuor gradus processusque eius

21 The word puer in Latin means "child", ,son", ,"boy". While relying on this word, we can proceed to the stage of human life determined as puerilitas or pueritia and puerities meaning "childhood" or "boyish age".

22 The word inberbis is an alternative form of the adjective imberbis meaning "without a beard".

23 In private Roman law, a male citizen obtained his full legal capacity at the age of 14 and stopped being under potential custody (tutela impuberum). It should be considered that Horace did not utilize the legal word tutela but custodia. Cicero used a similar term in reference to young people in his defense speech of Marcus Caelius, cf. Cic. Cael, 11: tot igitur annos versatus in foro sine suspicione, sine infamia, studuit Catilinae iterum petenti. quem ergo ad finem putas custodiendam illam aetatem fuisse? In the lattercase, the speech concerned a 26 -year-old person so it is doubtful that the term custodia was identified with age limits determined in private Roman law.

24 Ch. Laes, J. Strubbe, op. cit., p. 25. 
inveniet. 5 Prima aetas sub regibus fuit prope per annos quadringentos, quibus circum urbem ipsam cum finitimis luctatus est. Haec erit eius infantia. 6 Sequens a Bruto Collatinoque consulibus in Appium Claudium Quintum Fulvium consules centum quinquaginta annis patet, quibus Italiam subegit. Hoc fuit tempus viris armis incitatissimum, ideoque quis adulescentiam dixerit. 7 Deinceps ad Caesarem Augustum centum et quinquaginta anni, quibus totum orbem pacavit. Hic iam ipsa iuventus imperii et quasi robusta maturitas. 8 A Caesare Augusto in saeculum nostrum haud multo minus anni ducenti, quibus inertia Caesarum quasi consenuit atque decoxit, nisi quod sub Traiano principe movit lacertos et praeter spem omnium senectus imperii quasi reddita iuventute reviruit.

In the text cited above, Florus suggested that the history of Rome should be treated as human life and divided into four consecutive stages, the way it is done for humans. The first stage is named infantia, i.e. the childhood of Rome, lasting about four hundred years and taking place during the ruling of the kings, when Romans were fighting with their neighbors. The next stage occurred during the time when Brutus and Collatinus served the function of consul until the time when this office was held by Appius Claudius and Quintus Fulvius. This was the time of the youth of Rome (adulescentia), which lasted about one hundred and fifty years. ${ }^{25}$ During that time, Rome subordinated Italy and organized many armed excursions, expanding its territorial scope. In the next stage, which lasted over one hundred and fifty years until the times of Ceasar Augustus, Rome had its age of maturity and adulthood. The next stage of passivity, which lasted about two hundred years, was determined as old age (senectus) by Florus.

The next classification concerns the division of life into five stages. This theory was popular in ancient Rome. ${ }^{26}$ Censorinus, a Roman grammarian and writer, in his work De Die Natali ${ }^{27}$, cites the division of life put forward by Varro, a writer and scientist, in the following way:

Censor. DN, XIV,2: Varro quinque gradus aetatis aequabiliter putat esse divisos, unumquemque scilicet praeter extremum in annos $X V$. Itaque primo gradu usque annum $X V$ pueros dictos, quod sint puri, id est inpubes. Secundo ad tricensimum annum

25 The number of 150 years, provided by Florus is in this case incorrect. Brutus and Collatinus performed the function of consuls in 509 BC, and Appius Clauduis and Quintus Fulvius in 212 BC. The difference between those years is 297 .

26 Ch. Laes, J. Strubbe, op. cit., p. 26.

27 Cf.: P. Forisek, Censorinus és müve a Die natali, Debrecen, 2003, p. 225; K. Brodersen, Censorinus. Das Geburtstagsbuch. Übersetzt und erläutert von Kai Brodersen, Darmstadt 2011, p. 118; H.N. Parker, The Birthday Book by Censorius, Chicago-London 2007, p. 102. 
adulescentes, ab alescendo sic nominatos. In tertio gradu qui erant usque quinque et quadraginta annos, iuvenis annos appellatos eo quod rem publicam in re militari possent iuvare. In quarto autem adusque sexagensimum annum seniores vocitatos, quod tunc primum senescere corpus inciperet. Inde usque finem vitae uniuscuiusque quintum gradum factum, in quo qui essent, senes appellatos, quod ea aetate corpus iam senio laboraret.

From the passage quoted above it follows that Varro made a division of human life into five stages, with each stage, except the last one, lasting fifteen years. ${ }^{28}$ Childhood (pueritia) was the first stage of life which lasted until the age of 15 . Varro pointed that children are puri, which means clean in the spiritual meaning and cheerful. The next stage of human life, which lastedfrom the age of 15 until the age of 30 was maturity (adolescentia). This term comes from the verb adolesco, ere which means entering into adulthood, maturation. Then, until the age of 45 , a person was in the age of youth (iuvenitas). This term comes from the verb iuvo, are which means supporting, helping, as according to Varro young people supported the republic with a sword in their hands. A human being in the fourth stage of life, which lasted until the age of 60 , was named as senior, which came from the verb senesco, ere meaning aging. After the age of 60, old age (senectus) started in human life, as the human body was surrounded by senium - disability. The last of those stages, obviously, was not limited by time and ended with the death of the human being.

Apart from Censorinus, there was another Roman grammarian who understood human life as divided into four stages, the way it was performed by Varro. Servius, who lived between the $4^{\text {th }}$ and $5^{\text {th }}$ centuries AD, stated that Varro divided human life into four stages: infantia, pueritia, adulescentia, iuvenia and senecta. ${ }^{29}$ On such an assumption, it is impossible to link the above mentioned numerical divisions of age [i.e. 15 years each - note: W. Kosior] with each of the stages. On the contrary, this would lead to an irrational conclusion that a human being in ancient Rome remained in the stage of childhood until the age of thirty.

28 A numerological division into stages fifteen years long is based on the calculation of $5 \times 3$, as each of the stages comprises of the initial, medium and final part which last 5 years on average, cf.: Ch. Laes, J. Strubbe, op. cit., p. 26.

29 Cf.: Serv. Comm. Aen. 5,295: forma insignis id est decorus. viridique ivventa aetates omnes Varro sic dividit: infantiam, pueritiam, adulescentiam, iuventam, senectam. hae tamen, sicut etiam de temporibus supra diximus, singulae trifariam dividuntur, ut sit prima, viridis, praeceps: hinc est et 'viridi iuventa', et "cruda deo viridisque senectus". item Sallustius "sed Mithridates extrema pueritia regnum ingressus matre sua veneno interfecta". 
Consequently, the passage of Censorinus deserves attention, as the division corresponds the most closely with the reality of ancient Rome. At the age of about 15 , a boy became a man and received a gown, then at the age of about 30 - he usually started his career in the Senate, and then at the age of 46 he was discharged from the military duty for the republic. ${ }^{30}$

Table 4. Five stages of human life according to Varro

\begin{tabular}{cc}
\hline Stage of life & Age \\
\hline Childhood (pueritia) & $0-15$ years \\
Adolescence (adulescentia) & $15-30$ years \\
Youth (iuvenitas) & $30-45$ years \\
Aging (senior) & $45-60$ years \\
Old age (senectus) & over 60 years \\
\hline
\end{tabular}

The five-stage classification also appears in Plutarch, one of the greatest ancient writers of Greek origin, in the work called Amatorius. ${ }^{31}$ The theory appeared the following way:

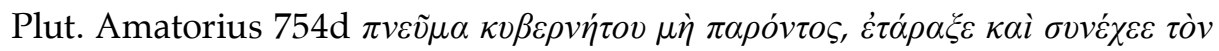

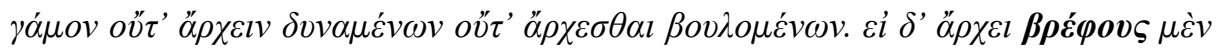

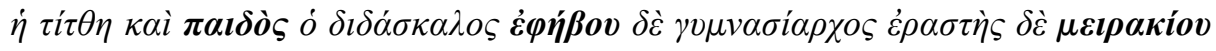

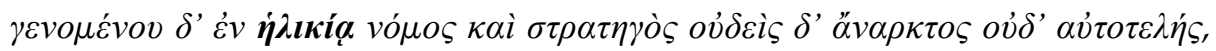

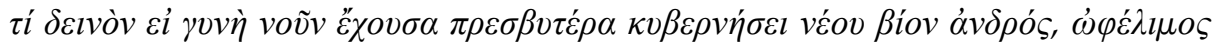

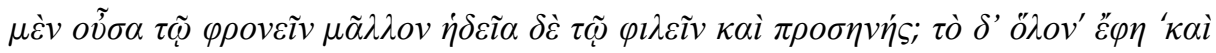

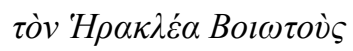

As follows from the above passage, Plutarch thought that a human being passes through the following stages: the infant stage ( $\beta \rho \varepsilon \dot{\varphi} \varphi \varsigma$, , brephos $\left.{ }^{32}\right)$, childhood ( $\pi \alpha \tilde{\iota} \varsigma$,

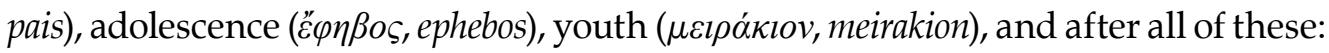

30 E. Eyben, De jonge Romein volgens de literaire bronnes der periode c. 200 v. Chr. Tot c. 500 n. Chr., Brussels 1977, pp. 22-23.

31 Compare: W.W. Goodwin, Plutarch. Plutarch's Morals. Translated from the Greek by several hands. Corrected and revised by William W. Goodwin, Vol. 1-4, Boston 1874; G. Bernardakis, Plutarchi Chaeronensis moralia Vol. 1-8, Leipzig, 1888-1896.

32 The term $\beta \rho \varepsilon ́ \varphi \rho \varsigma$ (brephos) in ancient Greece was compared to a newborn, an infant or unborn child, cf.: R.L. Overstreet, op. cit., p. 539. 
adulthood ( $\dot{\eta} \lambda \imath \kappa i \alpha$, hlikia). Adolescence occurred between the ages of $14-15$ and youth between the ages of $15-18 .^{33}$

The next division to be presented, in order of number, is the one which contains six stages of life. Such a categorization was performed by saint archbishop Isidore from Seville between the $6^{\text {th }}$ and $7^{\text {th }}$ century AD. Obviously, he was not a man of Antiquity but he described his knowledge to have fully arisen from ancient sources. ${ }^{34}$ What is more, he was called the "last scholar of Antiquity". ${ }^{35}$ That is why the division of human life made by Isidore from Seville in his work Etymologiarum sive Originum ${ }^{36}$ can be included among the divisions of life which were used in ancient Rome.

According to Isidore from Seville, human life was divided the following way:

Isid. Orig. XI, 2, 1-8, Gradus aetatis sex sunt: infantia, pueritia, adolescentia, iuventus, gravitas atque senectus. 2 Prima aetas infantia est pueri nascentis ad lucem, quae porrigitur in septem annis. 3 Secunda aetas pueritia, id est pura et necdum ad generandum apta, tendens usque ad quartumdecimum annum. 4 Tertia adolescentia ad gignendum adulta, quae porrigitur usque ad viginti octo annos. 5 Quarta iuventus firmissima aetatum omnium, finiens in quinquagesimo anno. Quinta aetas senioris, id est gravitas, quae est declinatio a iuventute in senectutem; nondum senectus sed iam nondum iuventus, quia senioris aetas est, quam Graeci $\pi \rho \varepsilon \sigma \beta \dot{\tau} \tau \eta v$ vocant. Nam senex

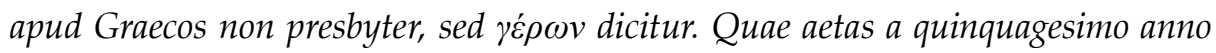
incipiens septuagesimo terminatur. 7 Sexta aetas senectus, quae nullo annorum tempore finitur; sed post quinque illas aetates quantumcumque vitae est, senectuti deputatur. 8 Senium autem pars est ultima senectutis, dicta quod sit terminus sextae aetatis.

According to the above passage, human life was divided into six stages: the stage of early childhood (infantia), childhood (pueritia), adolescence (adolescentia), youth (iuventus), maturity (gravitas) and old age (senectus). The stage of early childhood lasted from birth until the age of 7 . Childhood occurred from the age of 7 until 14 and it was the time when a human being was unable to procreate. This ability

33 E. Eyben, Children in Plutarch, [in:] L. Van der Stockt (ed.), Plutarchea Lovaniensia. A Miscellany of Essays on Plutarch, Leuven 1996, p. 82.

34 "Isidore himself emphasizes that he is indebted to ancient sources for his knowledge about life divisions", cf.: Ch. Laes, op. cit., p. 94.

35 A. Preus, Historical Dictionary of Ancient Greek Philosophy, Lanham 2015, p. 208 (s.v. Isidore of Seville); T. Curnov, The Philosophers of the Ancient World: An A-Z Guide, Bristol 2011, p. 159 (s.v. Isidore of Seville).

36 Compare: S.A. Barney, W.J. Lewis, J.A. Beach, O. Berghof, The Etymologies of Isidore of Seville, Cambridge 2006, p. 475; G.A. Kennedy, Classical Rhetoric \& Its Christian E Secular Tradition from Ancient to Modern Times, Chapel Hill-London 1999, pp. 203 et seq.; J. Henderson, The Medieval World of Isidore of Seville. Truth from Words, Cambridge 2007, pp. 143 et seq. 
started with the next stage of life when a human being entered the age of adolescence, lasting until the age of 28 . Next, until the age 50 , a person enjoyed youth, characterized by the strongest vitality. The period between youth and old age, lasting from the age of 50 until 70 was called gravitas, which is a period of maturity or dignity. At this stage, a person is not yet old but also not young anymore. The Greeks called such people $\pi \rho \varepsilon \sigma \beta \dot{v} \tau \eta v$ (presbyter). The last stage, distinguished by Isidore of Seville was old age.

Table 5. Six stages of human life by Isidore from Seville

\begin{tabular}{cc}
\hline Stage of life & Age \\
\hline Early childhood (infantia) & $0-7$ years \\
Childhood (pueritia) & $7-14$ years \\
Adolescence (adolescentia) & $14-28$ years \\
Youth (iuventus) & $28-50$ years \\
Maturity (gravitas) & $50-70$ years \\
Old age (senectus) & over 70 years \\
\hline
\end{tabular}

The seven-stage division of life was particularly common in the ancient world. The number seven was understood as an ideal number which constituted the basis of the universe. There were seven planets, seven colors, seven metals and seven spheres. ${ }^{37}$

The most important division of stages of human life in ancient Rome was the division made by Ptolemy, an astronomer and scholar of Greek origin, who acted in the $2^{\text {nd }}$ century AD. ${ }^{38}$ The division, which Ptolemy suggested in the work Tetrabiblos ${ }^{39}$, is a combination of symbols, i.e. that of the number seven with the astronomic meaning of seven planets. Ptolemy based his 7-stage division of human life on the distance of each planet from the Earth. This distance was calculated in years, i.e. through the calculation of time needed in order to arrive ata particular planet. ${ }^{40}$

\footnotetext{
37 Ch. Laes, op. cit., p. 88.

38 About the Greek division of human lifeinto seven stages, cf.: R.L. Overstreet, op. cit., pp. 537-563; F. Boll, Die Lebensalter; ein Beitrag zur antiken Ethologie und zur Geschichte der Zahlen, mit einem Einhang über die Schrift von der Siebenzahl, Lepzig-Berlin 1913, pp. 121(33)-124(36).

39 W.G. Waddell, Manetho. With an English Translation (Ptolemy. Tetrabiblos. Edited and Translated Into English by F.E. Robbins.), London 1940, p. 860.

40 Ch. Laes, op. cit., p. 89.
} 
The first stage of human life, indentified with the moon ( $\Sigma \varepsilon \lambda \eta \dot{\eta} \eta$, Selene),was early childhood or infancy ( $\beta \rho \varepsilon \dot{\varepsilon} \varphi \varsigma$, brephos) lasting until the age of 4 . This is the time of lack of operational efficiency of the body, fast growth and lack of possibility to express oneself. ${ }^{41}$ Childhood ( $\pi \alpha \tilde{i} \varsigma$, pais) was the second stage, which lasted until

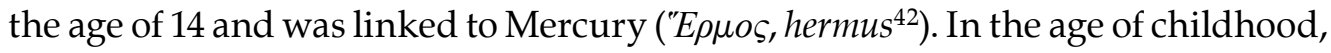
a human being started to form thoughts, understand the meaning of science together with the care of physical development as he performed his first gymnastic exercises. ${ }^{43}$ The third stage, until the age of 22 , was dominated by Venus (A $\varphi \rho \circ \delta i \tau \eta$, afroditis $^{44}$ ), and described by the term of adolescence ( $\mu \varepsilon \imath \rho \kappa \iota \iota \dot{\delta} \eta \varsigma$, meirakiodi), and it was the time of desire and love. During this age, a human being was obsessed with lust. ${ }^{45}$ The fourth stage of life lasted until the age of 41 and proceeded under

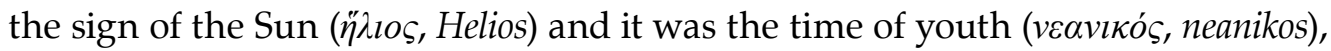
when a person was expected to seek glory and obtain a position in social and political life. A change of the current life full of amusement occurred which transformed itself to adopt a more ambitious attitude. ${ }^{46}$ The fifth stage, lasting until the age of 56, was the time of the highest activity of the planet of Mars ('A $\rho \varepsilon o \varsigma$, Ares ${ }^{47}$ )

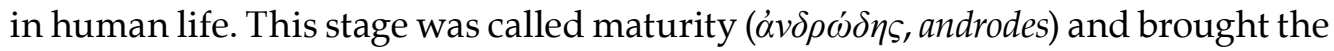
first problem of the body and soul. A person starts to be aware that his best ages have already passed, but he still tries to achieve something in life, before his end approaches. ${ }^{48}$ The sixth stage, lasting until the age of 68 , was old age ( $\pi \rho \varepsilon \sigma \beta v \tau \imath \kappa o ́ \varsigma$, presbitikos $\left.{ }^{49}\right)$, passing under the sign of Jupiter $\left(4 \tilde{i} o \varsigma, \operatorname{Dios}^{50}\right)$. In this stage, a human being, due to his lower physical forces, keeps off work and effort, and uses the

\footnotetext{
41 Ptol. Tetr. 4,10,205.

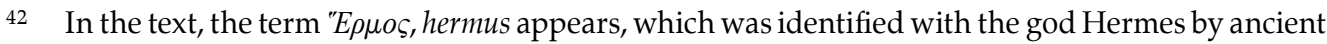
Greeks. The Roman equivalent of this god is Mercury.
}

${ }^{43}$ Ptol. Tetr. 4,10,205.

44 In the text, the term A $\varphi \rho o \delta i t \eta$, afroditis appears, which was identified with the goddess Aphrodite by ancient Greeks. The Roman equivalent of this goddess is Venus.

45 Ptol. Tetr. 4,10,205.

46 Ptol. Tetr. 4,10,206.

47 In the text, the term 'A $\rho \varepsilon \varsigma_{\text {, }}$ Ares appears, which was identified with the god Ares by ancient Greeks. The Roman equivalent of this god is Mars.

48 Ptol. Tetr. 4,10,206.

49 The term $\pi \rho \varepsilon \sigma \beta v \tau \imath \kappa o ́ \varsigma$, presbitikos is the closest in meaning to the Latin word "senilis", senile. In ancient Greece $\pi \rho \varepsilon \sigma \beta v \tau \imath \kappa o ́ \varsigma$, had a more pejorative character and meant an old-fashioned person with mental problems, cf.: P.A. Clark, The Balance of the Mind: The Experience and Perception of Mental Illness in Antiquity, Washington 1993, p. 71.

50 In the text, the term $\Delta \tilde{i}$ s, Dios appears, which was identified with the god Zeus by ancient Greeks. The Roman equivalent of this god is Jupiter. 
time to rest and think instead, while using his worldly wisdom and prudence. ${ }^{51}$ The seventh and last stage was late old age ( $\gamma \varepsilon \rho o v \tau \imath \kappa o s, ~ g e r o n t i k o s)$,which commenced after the age of 69. The equivalent of this stage was Saturn (Koóvov, Kronos ${ }^{52}$ ). In the last stage of life, where there was no timely limit, life definitely had lost its previous charm, an old person expressed dissatisfaction, lack of patience and became more despotic. ${ }^{53}$

Table 6. Seven stages of human life according to Ptolemy

\begin{tabular}{|c|c|}
\hline Stage & Age \\
\hline 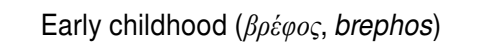 & $0-4$ years \\
\hline Childhood ( $\pi \alpha \tilde{\imath} \varsigma$, pais) & $5-14$ years \\
\hline Adolescence ( $\mu \varepsilon \iota \rho \alpha \kappa \iota \omega ́ \delta \eta \varsigma$, meirakiodi) & $15-22$ years \\
\hline 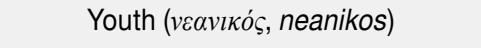 & $23-41$ years \\
\hline Maturity ( $\dot{\alpha} v \delta \rho \omega \dot{\delta} \eta\rceil$, androdes) & $42-56$ years \\
\hline 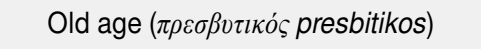 & $57-68$ years \\
\hline 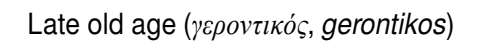 & over 69 years \\
\hline
\end{tabular}

While discussing Ptolemy and his theory concerning human life, it is necessary to point out that the above classification and the work discussed arose in the $2^{\text {nd }}$ century AD and referred to the then current social situation, that is the situation in the Roman Empire. According to Christian Laes, the division made by Ptolemy did not have much in common with astrology, the text is rather a description of human features which were prevailing among the representatives of elites of various ages in Imperial Rome. ${ }^{54}$

Human life in ancient Rome was also divided into seven stages by Macrobius, a Roman writer who lived between the $4^{\text {th }}$ and $5^{\text {th }}$ centuries. In his work Commentarii in somnium Scipionis ${ }^{55}$, he made the following division:

\footnotetext{
51 Ptol. Tetr. 4,10,206.

52 In the text, the term Koóvov, Kronos appears which was identified with the god Cronus by ancient Greeks. The Roman equivalent of this term is Saturn.

53 Ptol. Tetr. 4,10,207.

54 Ch. Laes, op. cit., p. 91.

55 Cf.: W.H. Stahl, Commentary of the Dream of Scipio by Macrobius, New York 1990, p. 281; B.C. BarkerBenfield, The Manuscripts of Macrobius' Commentary on the Somnium Scipionis, Oxford 1975, p. 315.
} 
Macrob. Somn. Scip. I,6 (...) post annos septem dentes qui primi emerserant allis aptioribus ad cibum solidum nascentibus cedunt, eodemque anno (id est septimo) plene absoluitur integritas loquendi: unde et septem uocales literae a natura dicuntur inuentae, licet Latinitas easdem modo longas modo breues pronuntiando quinque pro septem tenere maluerit, apud quos tamen, si sonos uocalium non apices numeraueris, similiter septem sunt. post annos autem bis septem ipsa aetatis necessitate pubescit. tunc enim moueri incipit uis generationis in masculis et purgatio feminarum. ideo et tutela puerili quasi uirile iam robur absoluitur: de qua tamen feminae propter uotorum festinationem maturius biennio legibus liberantur. post ter septenos annos genas flore uestit iuuenta, idemque annus finem in longum crescendi facit: et quarta annorum hedomas impleta in latum quoque crescere ultra iam prohibet. quinta omne uirium, quantae inesse uni cuique possunt, conplet augmentum nulloque modo iam potest quisquam se fortior fieri. inter pugiles denique haec consuetudo seruatur, ut quos iam coronauere uictoriae nihil in se amplius in incremento uirium sperent, qui uero expertes huius gloriae usque illo manserunt a professione discedant. sexies uero septeni anni seruant uires ante collectas, nec diminutionem nisi ex accidenti euenire patiuntur. sed a sexta usque ad septimam septimanam fit quidem diminutio sed occulta et quae detrimentum suum aperta defectione non prodat. ideo non nullarum rerum publicarum hic mos est, ut post sextam ad militiam nemo cogatur, in pluribus datur remissio iusta post septimam. notandum uero, quod, cum numerus septem se multiplicat, facit aetatem quae proprie perfecta et habetur et dicitur, adeo ut illius aetatis homo - utpote qui perfectionem et adtigerit iam et necdum praeterieritet - consilio aptus sit nec ab exercitio uirium alienus habeatur. cum uero decas qui et ipse perfectissimus numerus est perfecto numero id est 'c $\pi \tau \alpha \delta$ i iungitur ut aut decies septeni aut septies deni conputentur anni, haec a physicis creditur meta uiuendi, et hoc uitae humanae perfectum spatium terminator (...)

From the above passage, it follows that Macrobius divided human life into seven stages, relying on a seven-year unit of division. He did not designate certain terms or names to each of the stages, but he only presented the age of a human being starting with birth, adding or multiplying the number seven, which pointed the characteristics of each stage. The first stage lasted from birth until the age of 7 and it was the time when milk teeth were replaced by second teeth. At the same time, a human being would start developing speech. Then, between the age of 7 and 14, a person obtains the ability to procreate and the time of childhood together with the time of being under custody (tutela puerili) ends. In the next stage, which occurs between the ages of 14 and 21, a human being obtains the maximum height, and young men start developing beard son their faces. Between the ages of 21 and 28, the human body stops growing in height. The period between the ages of 28 and 35 is the time when a person can acquire the greatest physical 
strength. After this period, according to Macrobius, there was no possibility to acquire any more strength. That is why between the ages of 35 and 42 a human being kept the physical strength and could only lose it as a consequence of an accident. Together with the end of this period, an invisible process of weakening commenced, but its effects were not noticeable. A human being, in the next stage, which lasted between the age of 42 and 49, was in the best of his time, according to Macrobius. That was when the perfect number seven was multiplied by itself, which gave the exact result of forty nine. Macrobius also presented hints about the alleged length of human life. He pointed out that, from the physical point of view, the limit of life is reached with the age of 70 . After reaching this age, a human being was only capable of using his knowledge to give advice to others. ${ }^{56}$

The suggested division of human life into seven stages can be also found in Onomasticon $^{57}$, i.e. the work of Julius Pollux, a grammarian and scholar of the $2^{\text {nd }}$ century. Similarly, as was the case with the divisions presented above, he distinguished stages of early childhood (0-7years), childhood (7-14 years), adolescence (14-21 years), youth (21-28 years), adulthood ( $28-35$ years), maturity ( $35-42$ years) and old age (42-49 years). ${ }^{58}$ Pollux, contrary to other authors, pointed out that old age started after reaching the age of 42 , which is very early. ${ }^{59}$

In this article, the non-judicial sources which concerned the division of human life, have been analyzed. Consequently, it has been possible be determine that in ancient Rome there were several theories concerning this matter. The divisions of life into three, four, five, six and seven stages were very popular. Each theory had different justifications and various arguments. Among those, we can distinguish medical, psychological, numerical and also military-administrative arguments.

In order to sum up briefly, we can present some general concepts applied by Romans concerning the concepts of childhood, youth, old age and the terms used to describe them. In order to average out the results of the research, it maybe determined that in ancient Rome childhood was a period which lasted until the age of about 16. Most authors point the ages of 14 to 17 as the end of this period. The Latin term for childhood was used in almost all sources described herein. In terms of the Greek language, the term $\pi \alpha \tilde{l} \varsigma$ (pais) dominated. The period of youth, also called the medium period, lasted from the age of about 16 to 55 years. Most authors point the ages of 50 to 70 as the upper limit of this stage of life. This period included

\footnotetext{
$56 \quad$ Ibidem, p. 95.

57 Cf.: Iulli Pollucis Onomasticon cum Annotationibus Interpretum curavit Guilielmus Dindorfius, Leipzig 1824, p. 1198.

58 Compare: Pollux, Onom. 2,4.

$59 \quad$ Ch. Laes, J. Strubbe, op. cit., p. 27.
} 
adolescence, years of youth and maturity. For this phase, the following Latin terms prevailed: adulescentia and iuventa, and in case of Greek: veavıkós (neanikos). After the latter stage, old age commenced, which the authors universally denoted by the

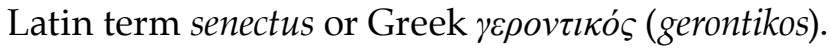

Moreover, the comparison of age limits in terms of legal capacity, distinguished in non-judicial sources together with the ones present in the Roman law, seems to be interesting. For private Roman law, the following age categories: 7,12,14 and 25 are characteristic, together with the terms linked to them: infantes, impuberes and puberes. This division does not correspond either to the classifications presented in non-juridicial Roman sources, and to terms utilized therein. However, it does not exclude the influence of the latter on the legal categorization of age. In order to determine the actual relation between both systems, broader research is essential, which would focus on both legal and non-legal sources of Roman law. This article is only a contribution to such research.

\section{Bibliography}

Barker-Benfield B.C., The Manuscripts of Macrobius' Commentary on the Somnium Scipionis, Oxford 1975.

Barney S.A., Lewis W.J., Beach J.A., Berghof O., The Etymologies of Isidore of Seville, Cambridge 2006.

Bernardakis G., Plutarchi Chaeronensis moralia Vol. 1-8, Leipzig, 1888-1896.

Boll F., Die Lebensalter; ein Beitrag zur antiken Ethologie und zur Geschichte der Zahlen, mit einem Einhang über die Schrift von der Siebenzahl, Lepzig-Berlin 1913.

Brodersen K., Censorinus. Das Geburtstagsbuch. Übersetzt und erläutert von Kai Brodersen, Darmstadt 2011.

Cierniakowa Z., Cyceron - Plutarch. Pochwała starości, Warszawa 1996.

Clark P.A., The Balance of the Mind: The Experience and Perception of Mental Illness in Antiquity, Washington 1993.

Coxe J.R., The writings of Hippocrates and Galen, Philadelphia 1846.

Curnov T., The Philosophers of the Ancient World: An A-Z Guide, Bristol 2011.

Eyben E., Children in Plutarch, [in:] Plutarchea Lovaniensia. A Miscellany of Essays on Plutarch, Leuven 1996.

Eyben E., De jonge Romein volgens de literaire bronnes der periodec. 200 v. Chr. Tot c. 500 n. Chr., Brussels 1977.

Falconer W.A., Cicero: De Senectute De Amicitia De Divinatione. With An English Translation, Harvard 1923.

Forisek P., Censorinus és müve a Die natali, Debrecen 2003.

Gollnick J., Religion and Spirituality in the Life Cycle, New York 2005. 
Goodwin W.W., Plutarch. Plutarch's Morals. Translated from the Greek by several hands. Corrected and revised by William W. Goodwin, Vol. 1-4, Boston 1874.

Harcum C.G., The Ages of Man: A Study Suggested by Horace, Ars Poetica, Lines 153-178, "The Classical Weekly" 1914, 7(15).

Henderson J., The Medieval World of Isidore of Seville. Truth from Words, Cambridge 2007. Iulli Pollucis Onomasticon cum Annotationibus Interpretum curavit Guilielmus Dindorfius, Leipzig 1824.

Jouanna J., Greek Medicine from Hippocrates to Galen. Selected papers, Leiden-Boston 2012.

Kennedy G.A., Classical Rhetoric \& Its Christian \& Secular Tradition from Ancient to Modern Times, Chapel Hill-London 1999.

Lacy P., de, Galen, On the doctrines of Hippocrates and Plato. Translation and Commentary, Berlin 2005.

Laes Ch., Children in the Roman Empire. Outsiders within, Cambridge 2011.

Laes Ch., Strubbe J., Youth in the Roman Empire. The Young and the Restless Years?, Cambridge 2014.

Lloyd G.E.R., The Hot and the Cold, the Dry and the Wet in Greek Philosophy, "The Journal of Hellenic Studies" 1964, 84.

Longrigg J., Greek Rational Medicine: Philosophy and Medicine from Alcmaeon to the Alexandirans, London 1993.

Mattern S.P., The Prince of Medicine. Galen in the Roman Empire, New York 2013.

Overstreet R.L., The Greek Concept of the "Seven Stages of Life" and Its New Testament Significance, "Bulletin for Biblical Research" 2009, 19(4).

Parker H.N., The Birthday Book by Censorius, Chicago-London 2007.

Preus A., Historical Dictionary of Ancient Greek Philosophy, Lanham 2015.

Skenazi C., Aging Gracefully in the Renaissance: Stories of Later Life from Petrarch to Montaigne, Leiden-Boston 2013.

Smart C., Buckley T.A., Horace. The Works of Horace, New York 1863.

Smart C., Horace. The Works of Horace, Philadelphia 1836.

Stahl W.H., Commentary of the Dream of Scipio by Macrobius, New York 1990.

Waddell W.G., Manetho. With an English Translation (Ptolemy. Tetrabiblos. Edited and Translated Into English by F.E. Robbins.), London 1940. 